\title{
СТРУКТУРНЫЕ ОСОБЕННОСТИ ЛИСТА ИЗ СПЛАВА Д16, ПОЛУЧЕННОГО ВАЛКОВЫМ ЛИТЬЕМ
}

\author{
А.Г. Пригунова, А.В. Ноговицын, И.Р. Баранов, М.В. Кошелев
}

Физико-технологический институт металлов и сплавов НАН Украины, г. Киев,Украина

Алюминиевый деформируемый сплав Д16 относится к системе $\mathrm{Al}-\mathrm{Cu}-\mathrm{Mg}$ и является наиболее распространенным представителем группы алюминиевых сплавов, применяемых в деформированном виде после обработки давлением в твердом состоянии и упрочняемых термической обработкой.

Энергосберегающей прогрессивной технологией получения листа является литье-прокатка [1], которая отличается от традиционного способа прокатки своеобразием процесса кристаллизации и формирования структуры. Основными упрочняющими фазами сплава Д16 являются интерметаллиды $\mathrm{S}\left(\mathrm{Al}_{2} \mathrm{CuMg}\right)$ и $\theta-\mathrm{CuAl}_{2}$. По литературным данным в интервале температур $20 \ldots 200^{\circ} \mathrm{C}$ растворимость компонентов практически не изменяется, а полное растворение интерметаллидных фаз достигается гомогенизацией при температуре $480 \ldots 500^{\circ} \mathrm{C}$, продолжительностью до 8 часов [2]. Учитывая особенности процесса литья-прокатки, в работе исследовали влияние выше указанного вида термической обработки на стуктуру листа из сплава Д16 при температуре $490{ }^{\circ} \mathrm{C}$, в течение $1 \ldots 5$ часов.

Прокатку осуществляли на двухвалковой установке литьяпрокатки с диаметром валков 420 мм, линия соединения центров которых расположена под углом 45 градусов к горизонтали. Длина бочки - 600 мм. Скорость охлаждения в межвалковом пространстве порядка $10^{3}{ }^{\circ} \mathrm{C} / \mathrm{c}$. Температуру гомогенизации определяли с учетом литературных данных [2] и результатов собственных исследований методом ДТА, представленных на рис. 1. 
Структура листа, полученного прокаткой из жидкого состояния (рис. 2 а), представлена зернами твердого раствора алюминия $\left(\mathrm{Al}_{\alpha}\right)$, по границам которых располагаются фазы $\mathrm{S}\left(\mathrm{Al}_{2} \mathrm{CuMg}\right)$ и $\theta-\mathrm{CuAl}_{2}$. Несмотря на довольно широкий диапазон изменения величины зерна $\mathrm{Al}_{\alpha}$ от 15 мкм до 70 мкм, поверхность листа характеризуется практически равномерным распределением зерен, средний размер которых составляет $30 \ldots 40$ мкм. Зерна твердого раствора $\mathrm{Al}_{\alpha}$ содержат элементы субструктуры глобулярной или приближенной к ней формы, с ободками по периметру, представляющими собой зоны с более высокой степенью пересыщения $\alpha$-фазы атомами легирующих и примесных элементов - наиболее вероятно, меди и магния.

По сечению листа толщиною 2,5 мм структура неоднородная: мелкокристаллическая (15...40 мкм) в слоях, соприкасающимися с поверхностью валков при прокатке, до грубых зерен размером $70 \ldots 250$ мкм на $1 / 2$ его сечения.

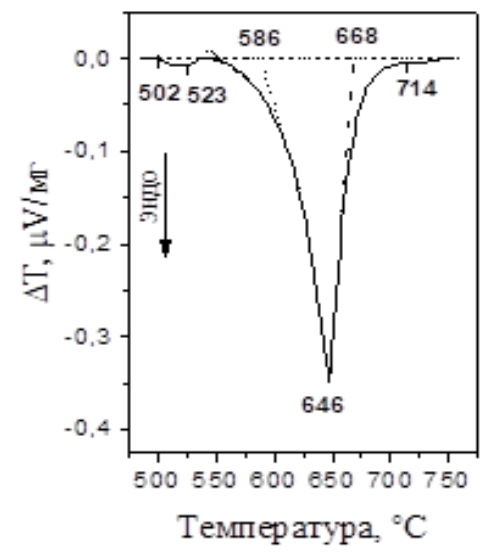

$a$

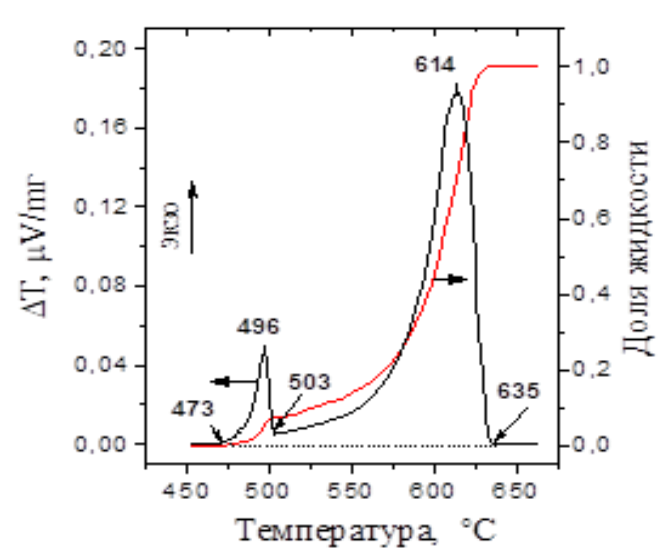

6

Рис. 1. Приведенные кривые ДТА плавления (а), кристаллизации (б) и ДЖТ (б) сплава Д16

Гомогенизация образцов листа из сплава Д16 при температуре $490{ }^{\circ} \mathrm{C}$ приводит к укрупнению зерен твердого раствора алюминия, которые на поверхности листа в зависимости от времени термической обработки в среднем составляют 70...200 
мкм (рис. 2 б, в). Увеличение времени выдержки до 3...5 часов (рис. 2 б, в; 3 б, в) приводит к формированию и выделению из пересыщенного твердого раствора алюминия интерметаллидных фаз, происходит рост и коагуляция $\theta$ - и S-фаз, которые выделяются как по границам зерен, так и внутри их. Появляются участки с пережогом. Однако структура по сечению (толщине) листа становится более однородная. Отсутствуют зоны с преимущественно мелкими или крупными зернами $\alpha$-фазы.

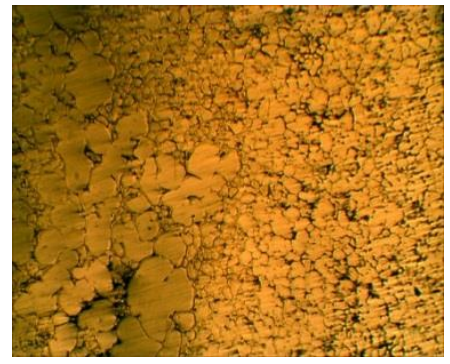

$a$

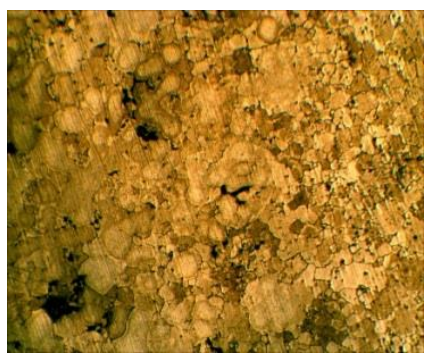

$\sigma$

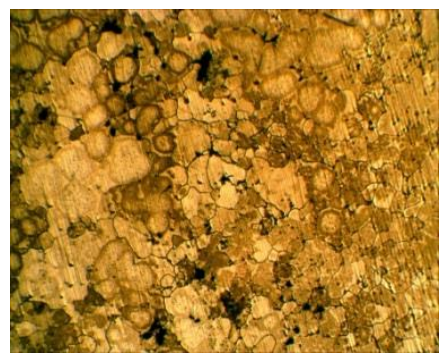

B

Рис. 2. Микроструктура сечения листа при литье-прокатке: $a-$ без термообработки; б - обработка 3 часа; в - обработка 5 часов, $\mathrm{x} 200$

Вывод: Специфичность процесса литья-прокатки по сравнению с прокаткой в твердом состоянии позволяет существенно сократить время термической обработки гомогенизацией листа из сплава Д16, которое не должно превышать более трёх часов.

\section{Литература}

2. Гридин А.Ю. Получение полос из высокопрочных алюминиевых сплавов валковой разливкой-прокаткой / А.Ю. Гридин, М. Шапер, В.Н. Данченко // Обработка металлов давлением. - 2011. - № 3 (28). - С. 184 - 194.

3. Захаров Е.Д., Ливанов В.А. Алюминиевые сплавы. Плавка и литье алюминиевых сплавов. Под ред. Добаткина В.С.- М.: Металлургия.- 1970 - C. $232-247$. 